\title{
Occupational health hazards and risk assessments in a wastewater treatment plant
}

\author{
Yazan Dannoun $^{1 *}$, Fatemeh Nouban ${ }^{1}$ \\ Department of Civil Engineering, Near East University, Nicosia, Mersin 10, Turkey
}

\section{ART ICLE INFO}

\section{ARTICLE HISTORY:}

Received: 06 June 2021

Revised: 18 June 2021

Accepted: 24 July 2021

Published: 31 July 2021

\section{KEYWORDS:}

Wastewater treatment plant, hazard identification, safety performance, health hazards, risk assessment

\begin{abstract}
A B S T R A C T
Wastewater treatment plant (WWTP) is considered one of the most dangerous sectors in the industrial field. Many workers still die each year due to poor awareness of workers about occupational health. Safety performance became important for different projects in the industrial field. Safety performance is concerned about the general behaviour of the workers in the worksite, usually, the performance can be evaluated by managing systems and identifying health hazards that can happen in the field. Many researchers tried to summary different methods to rate the safety performance. This paper describes the significant topics in risk assessment and hazard identification that have been done in the field of wastewater treatment plant (WWTP). The collected investigations have been arranged and sorted in this paper to set up strong basic information for the works in the field. Unlike the other studies, this paper is focused mainly on the safety performance, health hazard and risk assessment in the wastewater treatment plant (WWTP). This study has found the specific factors that can affect the performance of workers since the workers in general workplaces are facing difficulties in determining the hazards that can be resulted in serious problems such as injuries and death.
\end{abstract}

\section{INTRODUCTION}

Wastewater treatment plant (WWTP) became one of the most important projects in many countries, WWTP is responsible for the treatment operations of sewage wastewater. A wastewater treatment plant is created to treat the incoming wastewater from the sewage system by operations to be able for another use (Serdarevic and Dzubur, 2018). A wastewater treatment plant is considered a dangerous work environment because it has many chemical materials (Malakahmad et al., 2012). An analysis done by the (International Occupational Safety and Health, 2009) mentioned that no less than 15 accident hazards in WWTP, usually these hazards are varied such as physical, chemical, biological, ergonomic and psychosocial.

The workers in WWTP are dealing with machines, mechanical equipment and large numbers of chemical materials in order to treat the sewage water expose them to different hazards on their occupational health (Balasubramani and Rifai, 2015). As stated in (Al Batanony and EL Shafie, 2011) study, a huge amount of chemical and organisms make the deal with sewage waste dangerous since they transfer to the workers in different ways:

- Hand to mouth contact,

- The fecal-oral route (eating, drinking or smoking),

- Touching the face with contaminated hands,

- Inhalation of aerosols containing microorganisms.

\section{SAFETY PERFORMANCE IN WWTP}

Many chemical compositions are emitted during the process of water treatment, the low concentration of these compositions can affect the health of the people in the plant. Many workers in wastewater plants are suffering from anxiety, stress, headache and dizziness, nausea and loss of consciousness. Due to these compositions, a health risk assessment program has to be applied to check the workers since they are exposed to inhalation (Zhou et al., 2016; Drewnowski et al., 2018). The methods of checking the safety performance can be summarized as follows. 


\subsection{Accident rate}

This method is concerned with giving indicators for the number of accidents that happened during the implementation period of the project, usually, the contractors are responsible for giving a report described all the accidents with the workers (Bilir and Gurcanli, 2016).

\subsection{Incidence rate}

This way is interested with counting the total numbers of workdays that have been missed during the accident, this method gives a good indicator for evaluating how the rules of safety are applied to the workers in the project (ElMashaleh et al., 2007).

\subsection{Checklist}

This method is considered a very effective tool to evaluate safety performance, this method is used to monitor and identify all the items of safety procedure. This way helps to specify the nature of the hazard and assesses the applied safety (Alaqqad, 2009).

\section{ASSESSMENT OF RISK INCIDENCE}

Risk assessment and control in traditional projects have to be performed by identifying the nature of risk, in order to understand the risks many general steps have to be performed as described below (Han et al., 2008):

- Identification of the nature of risk,

- Analysis of the risk effect,

- Evaluation risk level,

- Response and decision making,

- Monitoring to avoid risk.

Pinto et al. (2011) Stated in their study that, most of the studies that have been done in risk assessment are relayed on main three principles, the first one is defining the potential hazards, the second one is assessing the risks, and Hierarchy of the risks. Malakahmad et al. (2012) conducted an investigation to assess the hazards in the sewage treatment plant, the hazards were ranked and sorted regarding the likelihood of the risk and degree of the severity Equation 1 describes the risk assessment.

$$
\text { Risk }=\text { likelihood } \times \text { severity }
$$

Risk assessment in any project depends on many factors, these factors may have positive or negative effects on the objectives of the projects. At the beginning of risk assessment, all the factors should break down and be sorted. As described before in previous studies, risk depends on special criteria involved in the probability of the risk occurrence and the impact of results of the risk. In the risk assessment stage, the probability of occurrence and severity of the risk has to be defined (Zhi, 1995).

\section{CAUSES AFFECTING SAFETY PERFORMANCE}

Several factors can affect the workers during their job, each factor associates with risk. Usually, these factors have to be analyzed and evaluated in order to assess the level of the resulted risk (Pinto et al., 2011). Generally, these factors are varied from project to project. It was noticed that risk causes have resulted from different factors such as, lack of safety and health gaudiness in the workplace, the company's budget does not cover the safety plan, lack of training programs, supervision and awareness for the different tasks (i.e., plumbing, electric and maintenance), lack in information related to standards, and frequently changing in given tasks. Table 1 describes some factors collected from different previous studies (Loosemore et al., 2012; Cheng et al., 2010; Sertyesilisik et al., 2010).

Table 1. General factors affecting the performance of workers

\begin{tabular}{|c|c|c|c|}
\hline Item & Factors & Item & Factors \\
\hline 1 & $\begin{array}{l}\text { Poor work and safety } \\
\text { organization }\end{array}$ & 9 & $\begin{array}{l}\text { Workers are not } \\
\text { familiarized with } \\
\text { machine and } \\
\text { equipment }\end{array}$ \\
\hline 2 & $\begin{array}{l}\text { Limited budgets for } \\
\text { health and safety } \\
\text { measures }\end{array}$ & 10 & $\begin{array}{l}\text { Workers are much } \\
\text { more responsible }\end{array}$ \\
\hline 3 & Lack of coordination & 11 & $\begin{array}{l}\text { Inadequate training } \\
\text { and fatigue of } \\
\text { practitioners }\end{array}$ \\
\hline 4 & $\begin{array}{l}\text { Economic and time } \\
\text { pressure }\end{array}$ & 12 & $\begin{array}{l}\text { Bad equipment } \\
\text { selection, use or } \\
\text { inspection }\end{array}$ \\
\hline 5 & $\begin{array}{l}\text { Lack of information } \\
\text { about hazards, } \\
\text { accidents }\end{array}$ & 13 & $\begin{array}{l}\text { Poor safety } \\
\text { awareness of top } \\
\text { management and } \\
\text { project managers }\end{array}$ \\
\hline 6 & $\begin{array}{l}\text { Poor communications } \\
\text { both internal and } \\
\text { external }\end{array}$ & 14 & $\begin{array}{l}\text { Lack of } \\
\text { prevention/protection } \\
\text { equipment }\end{array}$ \\
\hline 7 & $\begin{array}{l}\text { Poor involvement of } \\
\text { workers in safety } \\
\text { matters }\end{array}$ & 15 & $\begin{array}{l}\text { Construction jobs } \\
\text { can be far apart }\end{array}$ \\
\hline 8 & $\begin{array}{l}\text { Constantly changing } \\
\text { worksite }\end{array}$ & 16 & $\begin{array}{l}\text { Workers face long- } \\
\text { term health risks } \\
\text { from the stress }\end{array}$ \\
\hline
\end{tabular}

\section{HAZARD IDENTIFICATIONS}

Hazard identification is related to how to prevent the accident, generally hazard identification depends on site 
inspection. Injuries can happen because most of the managers fail to do full check for all the places in the worksite (Kim et al., 2013). Types of hazards can be categorized as follow:

- Obvious hazards: such as moving machinery, unstable ground, explosive and misfire. These hazards are related to managers and employees, who do not contract with those hazards,

- Hidden hazards: these hazards are suspended with unseen hazards such as gas leaks, electric faults, hydraulic pressure and weather conditions,

- Trivial hazards: these hazards are produced minor injuries such as slipping, spillage and housekeeping.

\section{MAIN KINDS OF HAZARD IN WWTP}

The wastewater treatment plant has many aspects that have to be considered and identified in the workplace. These aspects are important because they are associated with health and safety, and they can be conducted by identifying the hazards, assessing the risks and following guidelines and standards (Islam and Ryan, 2015; Ramesh et al., 2017).

\subsection{Chemical hazards}

Sewage water in the sanitary system includes many different materials such as; oils, salts, metals, and asbestos. Workers in wastewater treatment plants are exposed to these kinds of materials because of the nature of their work. These chemical and toxic materials infect the workers in different ways. The first route of exposure to these materials is by inhalation from the workers because sewage treatment plant has many open tanks for treatment operations, these operations make the aerial dispersion level high (Brown, 1997).

\subsection{Biological hazards}

Carducci et al. (2018) conducted an investigation of the number of biological agents that can be transferred to the workers, they mentioned in their study that a model should be applied in WWTP in order to see the risk level of the epidemiological illness that can affect the workers. They noticed in their study that the pathogens in the sewage plant are widely spread especially in the situation of adenovirus.

Workers are suffering from various health symptoms because they are facing many airborne contaminants in the treatment plant. Lee et al. (2007) Studied the relationship between biological materials (hydrogen sulfide and endotoxin) among wastewater treatment plant workers through personal monitoring program, they found that the workers have many symptoms such as higher odds ratios of respiratory, ocular and skin irritation, neurology, and gastrointestinal symptoms.

\subsection{Physical hazards}

Sulojeva et al. (2011) summarized the main physical hazards that can be happened for workers during the maintenance work, falling in the aeration basin chamber, being exposed to bad weather like snow or over hot, exposing to high-level noise from blowers and directly contacting with cables and electrical machines and equipment. (Malakahmad et al., 2012) conducted their study on some physical hazards that can be resulted in fatal for the workers during their job, Table 2. Shows the hazards that can affect the worker from the physical prescriptive.

Table. 2. Physical hazards

\begin{tabular}{|c|l|}
\hline Item & Hazards \\
\hline $\mathbf{1}$ & Slippery floors cause falling \\
\hline $\mathbf{2}$ & Hazards resulted by falling heavy articles \\
\hline $\mathbf{3}$ & Exposure to high noise level from machine \\
\hline $\mathbf{4}$ & Falls into ponds, pits, clarifiers or tanks \\
\hline $\mathbf{5}$ & Electric shock \\
\hline $\mathbf{6}$ & Flying particles causing injury \\
\hline $\mathbf{7}$ & Spreading gases during processing \\
\hline
\end{tabular}

\section{CONTROLLING OF RISK INCIDENCE}

Tiwari (2008) highlighted in their study that, the workers in WWTP have to get benefits from the occupational health services, which health monitoring program has to be performed periodically. Also, a regular program should be done for awareness to share safety working procedures and protective devices have to be used by workers.

Health and safety-first aid have to be ready in an adequate way as regulations, mandatory list items and requirements from the employers to provide appropriate help for employees when they get injured or taken ill at the workplace in WWTP (Shafik et al., 2019).

Some instructions are suggested by (Spellman and Welsh, 2017), in order to reduce the risk incidence in wastewater treatment plants, these instructions are described below:

- Highlighting the safe work practice and warning labels regarding OSHA requirements,

- Safety training program for workers should be done by the safety engineer,

- The district spaces in the workplace should be audited on a routine program,

- A first aid training program should be given.

Hazard inspection from OSHA respective has many stages to be performed (OSHA, 2016). The hazards in the workplace can be described as a station, equipment or maintenance that have been neglected to be under control. Inspection has to be done for the staff before start working, to set up this stage some records have to be taken such as: 
- Conducting an inspection for all the places that related to the work and make from the sources that can be a hazard,

- Inspection for all the activities that are performed in the worksite, storage and warehousing, these activities can be working with tools and small machines that can affect the workers,

- Different checklists have to be prepared for each task or mission in the work such as (electrical work, equipment operation, protection of fire, problems come from ergonomic of worker, slip and fall hazards, and the maintenance of the machines),

- Before changing the plan in the work, evaluation has to be performed to prevent the risk occurrence.

Sulojeva et al. (2011) hazard in a wastewater treatment plant can be eliminated or, reduced their risks, by providing the workers with protective clothes, respirators, gas masks, safety goggles, gloves, safety boots and safety strips.

\section{CONCLUSIONS}

An over review was conducted to identify the health hazards that can be happened in the wastewater treatment plant. This study provides the most important factors that can affect the workers during their works. Safety performance and the main kinds of hazards were summarized to improve the awareness of workers in the workplace. the methods of risk controlling were identified and described clearly in order to minimize the accident in the wastewater treatment plants.

\section{CONFLICT OF INTEREST STATEMENT}

The authors declare that there is no conflict of interest.

\section{REFERENCES}

[1] Al Batanony, M. A., \& EL Shafie, M. K. (2011). Workrelated health effects among wastewater treatment plants workers. International Journal of Occupational and Environmental Medicine, 2(4), 237-244.

[2] Alaqqad, M. K. (2009). Assessment of the factors affecting safety performance on construction projects in Gaza Strip. Master Dissertation, The Islamic university. http://hdl.handle.net/20.500.12358/19545

[3] Balasubramani, A., \& Rifai, H. S. (2015). Polychlorinated dibenzo-p-dioxins and polychlorinated dibenzofurans in sewage sludge: congener patterns, toxic equivalency and comparison with effluent concentrations and toxic equivalency. Water Resources Management VIII. Water Resources Management 2015. https://doi.org/10.2495/wrm150341

[4] Bilir, S., \& Gurcanli, G. E. (2016). A Method to Calculate the Accident Probabilities in Construction Industry Using a Poisson Distribution Model. In Advances in Safety Management and Human Factors (pp. 513-523). Springer, Cham. https://doi.org/10.1007/978-3-319-41929-9 47

[5] Brown, N. J. (1997). Health hazard manual: Wastewater treatment plant and sewer workers. Manuals and User Guides, 2.

[6] Carducci, A., Donzelli, G., Cioni, L., Federigi, I., Lombardi, R., \& Verani, M. (2018). Quantitative microbial risk assessment for workers exposed to bioaerosol in wastewater treatment plants aimed at the choice and setup of safety measures. International journal of environmental research and public health, 15(7), 1490.

https://doi.org/10.3390/ijerph15071490

[7] Cheng, C. W., Leu, S. S., Lin, C. C., \& Fan, C. (2010). Characteristic analysis of occupational accidents at small construction enterprises. Safety Science, 48(6), 698-707. https://doi.org/10.1016/j.ssci.2010.02.001

[8] Drewnowski, J., Makinia, J., Kopec, L., \& FernandezMorales, F. J. (2018). Modelization of nutrient removal processes at a large WWTP using a modified ASM2d model. International journal of environmental research and public health, 15(12), 2817. https://doi.org/10.3390/ijerph15122817

[9] El-Mashaleh, M. S., Edward Minchin Jr, R., \& O’Brien, W. J. (2007). Management of construction firm performance using benchmarking. Journal of Management in Engineering, 23(1), 10-17. https://doi.org/10.1061/(ASCE)0742597X(2007)23:1(10)

[10] Han, S. H., Kim, D. Y., Kim, H., \& Jang, W. S. (2008). A web-based integrated system for international project risk management. Automation in construction, 17(3), 342-356. https://doi.org/10.1016/j.autcon.2007.05.012

[11] International Hazard Datasheets on Occupation Wastewater Treatment Plant Operator (2009). International Occupational Safety and Health Information Centre (CIS): International Labor Organization (ILO).

[12] Islam, T., \& Ryan, J. (2015). Hazard mitigation in emergency management. Butterworth-Heinemann.

[13] Kim, H., Lee, H. S., Park, M., Chung, B., \& Hwang, S. (2013). Information retrieval framework for hazard identification in construction. Journal of Computing in Civil Engineering, 29(3), 04014052. https://doi.org/10.1061/(ASCE)CP.1943-5487.0000340

[14] Lee, J. A., Thorne, P. S., Reynolds, S. J., \& O'Shaughnessy, P. T. (2007). Monitoring risks in association with exposure levels among wastewater 
treatment plant workers. Journal of occupational and environmental medicine, 49(11), 1235-1248. https://doi.org/10.1097/JOM.0b013e3181568b40

[15] Loosemore, M., Raftery, J., Reilly, C., \& Higgon, D. (2012). Risk management in projects. Routledge. https://doi.org/10.4324/9780203963708

[16] Malakahmad, A., Downe, A. G., \& Fadzil, S. D. M. (2012). Application of occupational health and safety management system at sewage treatment plants. In 2012 IEEE Business, Engineering \& Industrial Applications Colloquium (BEIAC) (pp. 347-350). IEEE.

[17] Occupational Safety and Health Administration. (2016). Occupational safety and health standards: Safety \& Health Programs in Construction (Standard No. 1910.95). https://www.osha.gov/Publications/OSHA3886.pdf

[18] Pinto, A., Nunes, I. L., \& Ribeiro, R. A. (2011). Occupational risk assessment in construction industryOverview and reflection. Safety science,49(5), 616624. https://doi.org/10.1016/j.ssci.2011.01.003

[19] Ramesh, R., Prabu, M., Magibalan, S., \& Senthilkumar, P. (2017). Hazard identification and risk assessment in automotive industry. International Journal of ChemTech Research, 10(4), 352-358.

[20] Serdarevic, A., \& Dzubur, A. (2018). Importance and Practice of Operation and Maintenance of Wastewater Treatment Plants. In International Symposium on Innovative and Interdisciplinary Applications of Advanced Technologies (pp. 121-137). Springer, Cham.

[21] Sertyesilisik, B., Tunstall, A., \& McLouglin, J. (2010). An investigation of lifting operations on UK construction sites. Safety Science, 48(1), 72-79. https://doi.org/10.1016/j.ssci.2009.06.001

[22] Shafik, S., abdelmegeed, H., Saad, A., \& Abo Elnour, R. (2019). Occupational Health Hazards among Workers in Sewage Treatment Plants in Beni-Suef Governorate. IOSR Journal of Nursing and Health Science (IOSR-JNHS), Volume 8.

[23] Spellman, F. R., \& Welsh, K. D. (2017). Safe work practices for wastewater treatment plants. CRC Press. https://doi.org/10.1201/9781351246989

[24] Sulojeva, J., Percovs, A., Maļukova, J., \& Urbane, V. (2011). Occupational Safety Management Aspects on Municipal Waste Water Treatment Plant. Safety of Technogenic Environment, 1, 62-68.

[25] Tiwari, R. R., (2008). Occupational health hazards in sewage and sanitary workers. Indian Journal of Occupational and Environmental Medicine, 12(3), 112. https://doi.org/10.4103/0019-5278.44691

[26]Zhi, H. (1995). Risk management for overseas construction projects. International journal of project management, 13(4), 231-237. https://doi.org/10.1016/0263-7863(95)00015-I

[27]Zhou, Y., Hallis, S. A., Vitko, T., \& Suffet, I. H. M. (2016). Identification, quantification and treatment of fecal odors released into the air at two wastewater treatment plants. Journal of environmental management, 180, 257-263.

https://doi.org/10.1016/j.jenvman.2016.05.046 